The good prognosis of young women with angina should be noted with regard to the current uncertainty about the benefit which saphenous vein by-pass surgery may have on prognosis.

In conclusion, the incidence of I.H.D. in young women seems to be on the increase, but the cause of the rise in mortality in the years $1958-70$ is unexplained. The striking increase in the percentage of young women who smoke cigarettes and the increase in the number of cigarettes smoked may be a major contributor (Todd, 1972). If so, we can expect a steady increase in myocardial infarction in young women. This survey should be useful since it outlines many of the characteristics of women who develop angina or myocardial infarction at a young age, estimates prognosis, and might act as a reference with which to compare future studies of I.H.D. in young women.

\section{References}

Armstrong, A., et al. (1972). British Heart fournal, 34, 67.

Bengtsson, C. (1973). Acta Medica Scandinavica, Suppl No 549.

Blackman, N. S., and Kologlu, Y. (1961). NewYork State fournal of Medicine, 61, 3079 .

Brown, D. F., and Daudiss, K. (1973). Circulation, 47, 558.

Carlson, L. A. (1963). Journal of Atherosclerosis Research, 3, 334.

Cochran, R., and Gwinup, G. (1962). Archives of Internal Medicine, 110, 162.

Cumming, G. R., et al. (1973). British Heart fournal, 35, 1055.

Doerken, H. (1961). Koronarverschluss. Stuttgart, Thieme.

Doyle, J. T., et al. (1964). Fournal of American Medical Association, 190, 886.

Eliot, R. S., and Bratt, G. (1969). American fournal of Cardiology, 23, 633. Frings, C. S., Foster, L. B., and Cohen, P. S. (1971). Clinical Chemistry,
Gertler, M. M., et al. (1964). American fournal of Medical Science, 247, 145. Glancy, D. L., Marcus, M. L., and Epstein, S. E. (1971). Circulation, 44, 495. Goodale, F., Thomas, W. A., and O'Neal, R. (1960). Archives of Pathology, $69,599$.

Herman, M. V., and Gorlin, R. (1965). American fournal of Medicine, 38, 481 James, T. N., Post, H. W., and Smith, F. L. (1955). Annals of Internal Medicine, 43, 153.

Jurand, J., and Albert-Recht, F. (1962). Clinica Chimica Acta, 7, 522.

Kannel, W. B., Castelli, W. P., and McNamara, P. (1968). National Cancer Institute Monograph, 28, 9 .

Kemp, H. G., Elliott, W. C., and Gorlin, R. (1967). Transactions of the Association of American Physicians, 80, 59.

Lorimer, A. R., et al. (1974). British Heart fournal, 36, 192.

Malmcrona, R., et al. (1961). Acta Medica Scandinavica, 170, 301.

Mulcahy, R., Hickey, N., and Maurer, B. (1967). Circulation, 36, 577.

Mulcahy, R., Hickey, N., and Maurer, B. (1967). Circulat
Oliver, M. F., and Boyd, G. S. (1959). Lancet, 2, 690.

Oliver, M. F., and Boyd, G. S. (1959). Lancet, 2, 690 . Disease, ed. L. McDonald, p. 124. London, Pitman.

Oliver, M. F., et al. (1964). Lancet, 1, 891.

Oliver, M. F. (1970). British Medical fournal, 2, 210

Pickering, G. W. (1968). High Blood Pressure. London, Churchill.

Radford, D., and Oliver, M. F. (1973). British Medical fournal, 2, 428.

Rose, G. A., and Blackburn, H. (1966). Cardiovascular Population Studies: Methods. Geneva, W.H.O.

Shochet, B. R. (1960). Sinai Hospital fournal, 9, 206

Slack, J. (1969). Lancet, 2, 1380.

Stone, M. C., et al. (1971). Clinica Chimica Acta, 31, 333.

Sznajderman, M., and Oliver, M. F. (1963). Lancet, 1, 962.

Todd, G. F. (editor) (1972). Statistics of Smoking in the United Kingdom. London, Tobacco Research Council.

Weinreb, H. L., German, E., and Rosenberg, B. (1957). Annals of Internal Medicine, 46, 285.

World Health Organization (1968). Exercise Tests in Relation to Cardiovascular Function. Technical Report Service, No. 388. Geneva, W.H.O.

Winkelstein, W., Stenchever, M. A., and Lilienfeld, A. M. (1958). Fournal of Chronic Diseases, 7, 273

Wood, P. D. S., et al. (1972). Circulation, 45, 114.

\title{
Effect of Clofibrate on Blood Viscosity in Intermittent Claudication
}

\author{
J. A. DORMANDY， J. M. C. GUTTERIDGE， E. HOARE， T. L. DORMANDY
}

British Medical fournal, 1974, 4, 259-262

\section{Summary}

Sixty-two patients with intermittent claudication associated with peripheral arterial diseases were treated with clofibrate, $2 \mathrm{~g}$ daily, for a minimum of six months. Progress was compared with that in a similar pretreatment period and also with that of a matched untreated control group of 27 patients. The most striking effect of clofibrate was a steep and sustained fall in whole-blood viscosity measured over a wide range of shear rates. This was associated with a significant fall in abnormally raised initial plasma-fibrinogen levels. An increased proportion of patients on treatment showed evidence of clinical improvement. Clofibrate had no effect on the susceptibility of red blood cells to autoxidation but it led to a significant shift in the red cell fatty acid pattern.

St. George's and St. James's Hospitals, London

J. A. DORMANDY, F.R.c.s., Consultant Surgeon

Manchester Royal Infirmary, Manchester

E. HOARE, F.R.C.S., Senior Surgical Registrar

Whittington Hospital, London

J. M. C. GUTTERIDGE, M.I.BIOL., Senior Biochemist
T. L. DORMANDY, F.R.C.S., M.R.C.PATH., Consultant Chemical Pathologist

\section{Introduction}

Three considerations prompted a preliminary trial of clofibrate in intermittent claudication. Firstly, despite many technical advances vascular surgery can benefit only a few of these patients. For the rest no consistently successful treatment is available. Secondly, clofibrate has been shown to lower a raised plasma fibrinogen level (Cotton et al., 1963), and significant interrelations have now been established between plasma fibrinogen, wholeblood viscosity, blood flow, and the clinical manifestations and prognosis of the disease (Wells et al., 1964; Weaver et al., 1969; Merrill, 1969; Dormandy et al., 1973 a, b). Thirdly, clofibrate seems to benefit patients with angina pectoris independently of its action of lowering blood lipids (Physicians of the Newcastle upon Tyne Region, 1971; Research Committee of the Scottish Society of Physicians, 1971), and in some respects the two types of ischaemic pain are similar. It was felt, moreover, that a detailed study of the red cell fatty acids might clarify the striking but still unexplained relation between the susceptibility of red cells to oxidative damage (two-hour malonyldialdehyde) on the one hand and the symptoms, signs, and rheological abnormalities on the other (Dormandy et al., $1973 \mathrm{a}, \mathrm{b}$ ).

\section{Patients}

The patients were chosen mainly from the group of intermittent claudicants previously described (Dormandy et al., $1973 \mathrm{a}, \mathrm{b}$ ). Sixty-two patients were given clofibrate, $2 \mathrm{~g}$ daily, for a minimum of six months (mean $7 \cdot 4$ months). Their mean age ( \pm S.D.) was $62 \pm 8$ years, and there was the usual preponderance of men (47) 
TABle I-Changes in Biochemical Data in Pretreatment and Treatment Periods for Patients given Clofibrate

\begin{tabular}{|c|c|c|c|c|c|c|c|}
\hline & \multicolumn{4}{|c|}{ Pretreatment Period } & \multicolumn{3}{|c|}{ Treatment Period } \\
\hline & $\begin{array}{c}\text { Initial } \\
\text { Values } \\
\pm \text { S.D. } \\
\text { (A) }\end{array}$ & $\begin{array}{l}\text { Values at } \\
\text { Start of } \\
\text { Treatment } \\
\pm \text { S.D. } \\
\text { (B) }\end{array}$ & $\begin{array}{l}\text { Change (B-A) } \\
\pm \text { S.E. of Mean }\end{array}$ & $\mathbf{P}$ & 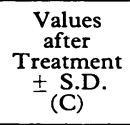 & $\begin{array}{l}\text { Change (C-B) } \\
\pm \text { S.E. of Mean }\end{array}$ & $\mathbf{P}$ \\
\hline $\begin{array}{l}\text { Cholesterol }(\mathrm{mg} / 100 \mathrm{ml}) \\
\text { Triglyceride }(\mathrm{mg} / 100 \mathrm{ml}) \\
\text { Fibrinogen }(\mathrm{mg} / 100 \mathrm{ml})\end{array}$ & $\begin{array}{l}271 \pm 49 \\
183 \pm 84\end{array}$ & $\begin{array}{l}265 \pm 50 \\
185 \pm 90 \\
426 \pm 96\end{array}$ & $\begin{array}{r}-6 \pm 5 \cdot 3 \\
2 \pm 8 \cdot 3\end{array}$ & $\begin{array}{l}\text { N.S. } \\
\text { N.S. }\end{array}$ & $\begin{array}{l}205 \pm 37 \\
135 \pm 70 \\
330 \pm 113\end{array}$ & $\begin{array}{l}-60 \pm 5 \cdot 3 \\
-50 \pm 7.8 \\
-96 \pm 19\end{array}$ & $\begin{array}{l}<0.001 \\
<0.001 \\
<0.001\end{array}$ \\
\hline
\end{tabular}

N.S. = Not significant.

over women (15). Clinically they were representative of the larger series (Dormandy et al., 1973 a). Their symptoms had been present for an average period of 32 months, their mean claudication distance was 328 yards, and $14 \%$ had rest pain. On examination only $10 \%$ had an absent femoral pulse, but $72 \%$ had no palpable ankle pulse on at least one side. Altogether $26 \%$ had a history of heart disease, $5 \%$ were diabetics, and $72 \%$ were cigarette smokers. The control group was matched for age, sex, and duration of symptoms. The distribution of blood flow pattern in the two groups was the same.

\section{Methods}

Clinical progress was assessed at regular intervals of one to two months by the same team of investigators. At the same times the blood flow in the legs was measured both at rest and after standard exercise. The plethysmographic techniques have been previously described (Dormandy et al., 1973 a).

The blood viscosity was measured in centipoises (cP) at two shear rates, 23 and $230 \mathrm{sec}^{-1}$, as described in earlier papers (Dormandy, 1970, 1971; Dormandy et al., 1973 a). At the final visits two additional measurements were made at lower shear rates, $2.62 \mathrm{sec}^{-1}$ and $0.77 \mathrm{sec}^{-1}$, using a Contraves viscometer. "Corrected" viscosities-that is, viscosities calculated to a standard packed cell volume (P.C.V.) of $45 \%$-were based on the previously established P.C.V./viscosity regression line applicable to this group of subjects.

The plasma fibrinogen, cholesterol, and triglycerides were measured, and the plasma lipoprotein pattern was assessed as previously described (Dormandy et al., 1973 a).

The susceptibility of the red blood cells to autoxidation was measured and expressed in terms of nanomoles of malonyldialdehyde (MDA) generated in two hours under standard oxidizing conditions (two-hour MDA); Dormandy, 1971; Stocks et al., 1972; Dormandy et al., 1973 a). After six months both treated

TABLE II-Mean Values ( \pm S.D.) of Cholesterol, Triglycerides, and Fibrinogen in 62 Patients Treated with Clofibrate and in 27 Untreated Patients

\begin{tabular}{|c|c|c|c|c|}
\hline & $\begin{array}{c}\text { Untreated } \\
\text { Patients }\end{array}$ & $\begin{array}{l}\text { Treated } \\
\text { Patients }\end{array}$ & $t$ & $\mathbf{P}$ \\
\hline $\begin{array}{l}\text { Cholesterol }(\mathrm{mg} / 100 \mathrm{ml}) \\
\text { Triglycerides }(\mathrm{mg} / 100 \mathrm{ml}) \\
\text { Fibrinogen }(\mathrm{mg} / 100 \mathrm{ml})\end{array}$ & $\begin{array}{l}247 \pm 53 \\
219 \pm 123 \\
420 \pm 116\end{array}$ & $\begin{array}{r}205 \pm 37 \\
135 \pm 70 \\
330 \pm 113\end{array}$ & $\begin{array}{l}4 \cdot 1 \\
3 \cdot 9 \\
3 \cdot 28\end{array}$ & $\begin{array}{l}<0.001 \\
<0.001 \\
<0.01\end{array}$ \\
\hline
\end{tabular}

and untreated control patients also had blood samples taken for fatty-acid analysis. This was carried out by gas-liquid chromatography after preliminary hydrolysis, extraction, and methylation of their red cell lipids. The technique, which incorporates several modifications of the method originally developed by Phillips et al. (1968), has been described in detail elsewhere (Gutteridge et al., 1973).

\section{Results}

Our preliminary assessment of the effects of clofibrate was based (a) on comparison with an immediate pretreatment period of the same duration, each patient acting as his or her own control, and (b) on comparison with an untreated control group.

The changes in plasma cholesterol, triglycerides, and fibrinogen in the clofibrate-treated patients are shown in table $I$ and fig. 1. The results of the treated and the control groups are compared in table II. The viscosity findings are summarized in tables III and IV and fig. 2. Both measured and corrected

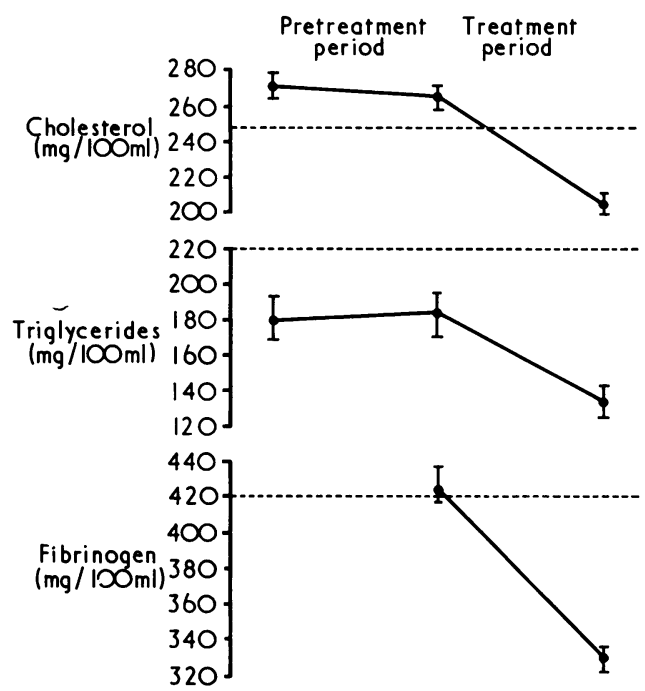

FIG. 1-Changes in plasma lipids and fibrinogen before and after treatment with clofibrate. For all changes and after treatment with clofibrate. For all changes
during treatment $P<0.001$. Dotted lines represent mean values for untreated patients.

TABLE III-Changes in Vicosity and Packed Cell Volume (P.C.V.) Levels in Pretreatment and Treatment Periods for Patients given Clofibrate

\begin{tabular}{|c|c|c|c|c|c|c|c|}
\hline & \multicolumn{4}{|c|}{ Pretreatment Period } & \multicolumn{3}{|c|}{ Treatment Period } \\
\hline & $\begin{array}{l}\text { Initial } \\
\text { Values } \\
\pm \text { S.D. } \\
\text { (A) }\end{array}$ & $\begin{array}{l}\text { Values at } \\
\text { Start of } \\
\text { Treatment } \\
\pm \text { S.D. } \\
\text { (B) }\end{array}$ & $\begin{array}{l}\text { Change (B-A) } \\
\pm \text { S.E. of Mean }\end{array}$ & $\mathbf{P}$ & $\begin{array}{c}\text { Values } \\
\text { after } \\
\text { Treatment } \\
\pm \text { S.D. } \\
\text { (C) }\end{array}$ & $\begin{array}{l}\text { Change (C-B) } \\
\pm \text { S.E. of Mean }\end{array}$ & $\mathbf{P}$ \\
\hline $\begin{array}{l}\text { Measured viscosity (cP) }\left\{\begin{array}{l}23 \mathrm{sec}^{-1} \\
230 \mathrm{sec}^{-1}\end{array}\right. \\
\text { P.C.V. (\%) } \\
\text { Corrected viscosity (cP) }\left\{\begin{array}{l}23 \mathrm{sec}^{-1} \\
230 \mathrm{sec}^{-1}\end{array}\right.\end{array}$ & $\begin{array}{l}7 \cdot 62 \pm 0.98 \\
4.73 \pm 0.55 \\
49 \cdot 0 \pm 3 \cdot 3 \\
6 \cdot 83 \pm 0.57 \\
4.32 \pm 0.53\end{array}$ & $\begin{array}{l}8 \cdot 05 \pm 1 \cdot 21 \\
4 \cdot 75 \pm 0.55 \\
48 \cdot 6 \pm 4 \cdot 3 \\
7 \cdot 08 \pm 0.60 \\
4 \cdot 34 \pm 0.27\end{array}$ & $\begin{array}{rl}0.53 & \pm 0.13 \\
0.02 & 0.07 \\
-0.40 \pm 0.40 & 0.40 \\
0 & 0.25 \\
0.02 & 0.10 \\
0.03\end{array}$ & $\begin{array}{l}<0.001 \\
\text { N.S. } \\
\text { N.S. } \\
\text { <o.02 } \\
\text { N.S. }\end{array}$ & $\begin{array}{l}7 \cdot 14 \pm 1 \cdot 10 \\
4.36 \pm 0.52 \\
46 \cdot 3 \pm 4 \cdot 5 \\
6 \cdot 76 \pm 0.63 \\
4 \cdot 16 \pm 0 \cdot 20\end{array}$ & $\begin{array}{r}-0.91 \pm 0.11 \\
-0.39 \pm 0.05 \\
2.30 \pm 0.34 \\
-0.32 \pm 0.11 \\
-0.18 \pm 0.03\end{array}$ & $\begin{array}{l}<0.001 \\
<0.001 \\
<0.001 \\
<0.01 \\
<0.001\end{array}$ \\
\hline
\end{tabular}


TABLE IV-Mean ( \pm S.D.) Viscosity at Various Shear Rates and Packed Cell Volume (P.C.V.) in 62 Patients treated with Clofibrate and in 27 Untreated Patients

\begin{tabular}{|c|c|c|c|c|}
\hline & Untreated Patients & Treated Patients & $t$ & $\mathbf{P}$ \\
\hline $\begin{array}{l}\text { Measured viscosity (cP) }\left\{\begin{array}{l}0.77 \mathrm{sec}^{-1} \\
2.62 \mathrm{sec}^{-1} \\
23 \mathrm{sec}^{-1} \\
230 \mathrm{sec}^{-1}\end{array}\right. \\
\text { P.C.V. (\%) } \\
\text { Corrected viscosity (cP) }\left\{\begin{array}{l}0.77 \mathrm{sec}^{-1} \\
2.62 \mathrm{sec}^{-1} \\
23 \mathrm{sec}^{-1} \\
230 \mathrm{sec}^{-1}\end{array}\right.\end{array}$ & 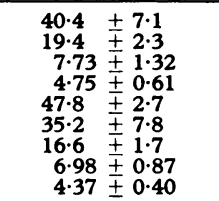 & 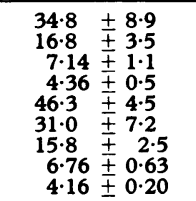 & $\begin{array}{l}2 \cdot 27 \\
2.75 \\
1.90 \\
2.74 \\
1.47 \\
1.99 \\
1.23 \\
1 \cdot 18 \\
3.07\end{array}$ & $\begin{array}{l}<0.05 \\
<0.01 \\
<0.1 \text { (N.S.) } \\
<0.01 \\
<0.2 \text { (N.S.) } \\
<0.05 \\
<0.3 \text { (N.S.) } \\
<0.3 \text { (N.S.) } \\
<0.01\end{array}$ \\
\hline
\end{tabular}

N.S. = Not significant.
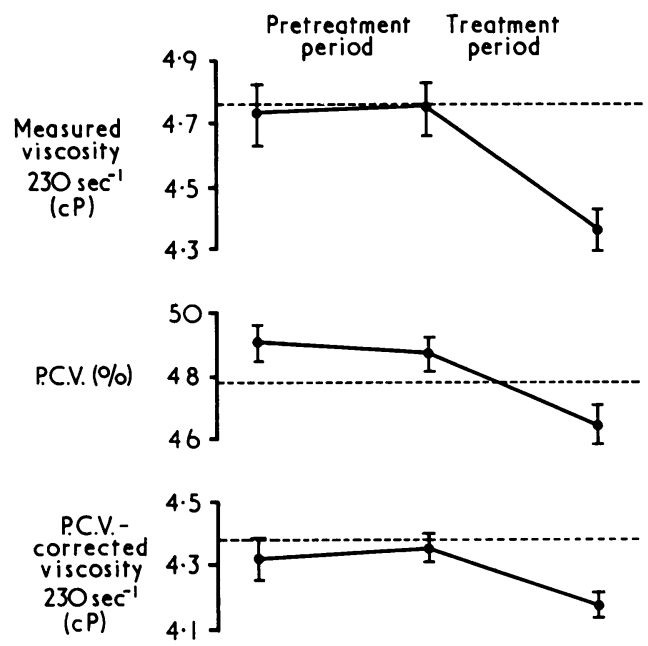

FIG. 2-Changes in measured and corrected viscosity before and after treatment with clofibrate. For all changes during treatment $P<0 \cdot 001$. Dotted lines represent mean values for untreated patients.

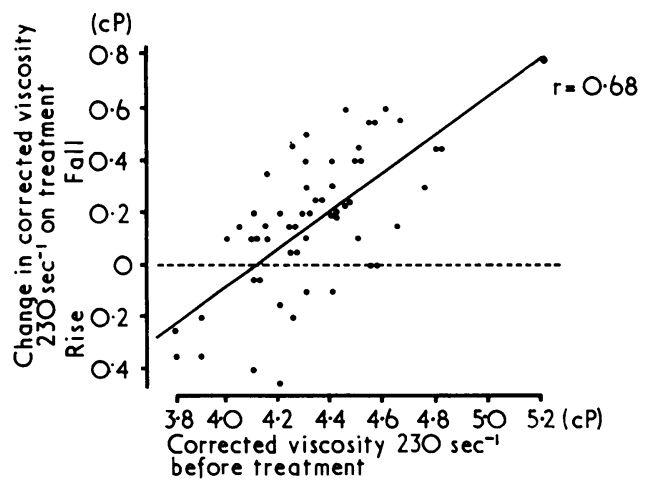

FIG. 3-Changes in corrected viscosity at $230 \mathrm{sec}^{-1}$ on treatment with clofibrate related to initial viscosities.

viscosities showed a significant drop on clofibrate treatment. (Because of a $2.3 \%$ fall in P.C.V. on treatment the effect of the drug was somewhat greater on measured than on corrected viscosity.) There was a close correlation between the initial plasma-fibrinogen levels and viscosities (at $230 \mathrm{sec}^{-1}$ ) on the one hand and the drop in both values on the other. In other words, the higher the initial values the greater the drop on clofibrate (fig. 3). The correlation lines intersected the level of zero change close to the normal values for both indices.

The results in both the treated and the untreated group confirmed the close correlation between blood viscosity and plasma fibrinogen in individual patients. Also confirming previous findings there was a close correlation between the two-hour red cell MDA and viscosity in untreated patients (and in the series of treated and untreated patients as a whole). The latter correlation did not depend on plasma fibrinogen or plasma lipids, none of which correlated directly with the two-hour MDA. Moreover, there was no significant difference in two-hour MDA between the untreated and clofibrate-treated group, and clofibrate, which significantly decreased viscosity, virtually abolished the viscosity/MDA correlation (table V).

TABLE v-Correlations between Corrected Viscosities and Two-hour Malonyldialdehyde

\begin{tabular}{|c|c|c|c|}
\hline \multirow{2}{*}{$\begin{array}{c}\text { Viscosity } \\
\text { (Shear-Rate) }\end{array}$} & \multicolumn{3}{|c|}{ Two-hour Malonyldialdehyde } \\
\hline & $\begin{array}{c}\text { Whole } \\
\text { Series } \\
(\mathrm{n}=80)\end{array}$ & $\begin{array}{c}\text { Untreated } \\
\text { Patients } \\
(\mathrm{n}=26)\end{array}$ & $\begin{array}{l}\text { Patients on } \\
\text { Clofibrate } \\
(\mathrm{n}=54)\end{array}$ \\
\hline $\begin{array}{l}230 \mathrm{sec}^{-1} \\
2 \cdot 62 \mathrm{sec}^{-1} \\
077 \mathrm{sec}^{-1}\end{array}$ & $\begin{array}{l}\mathbf{r}=0.36 \\
\mathbf{P}=0.001 \\
\mathbf{r}=0.37 \\
\mathbf{P}=0.001 \\
\mathrm{r}=0.44 \\
\mathbf{P}<0.001\end{array}$ & $\begin{array}{l}r=0.44 \\
P=0.07 \\
r=0.57 \\
P=0.03 \\
r=0.63 \\
P=0.01\end{array}$ & $\begin{array}{l}\mathbf{r}=0.39 \\
\mathbf{P}=0.09 \\
\mathbf{r}=0.11 \\
\mathbf{P}=\mathbf{N} . S . \\
\mathbf{r}=0.12 \\
\mathbf{P}=\text { N.S. }\end{array}$ \\
\hline
\end{tabular}

N.S. = Not significant.

Chromatographic analysis of the red cell fatty acid pattern provided negative answers to two questions raised by earlier findings (Dormandy et al., 1973 a). There was no correlation between the two-hour MDA and the relative concentration of the polyunsaturated fatty acids (the source of $\mathrm{MDA}$ ), and there was no consistent and significant correlation between the relative concentration of individual fatty acids or groups of fatty acids and the corrected viscosities. The findings also revealed a striking effect of clofibrate on the red cell fatty acid pattern. The most important changes were (a possibly reciprocal) fall in stearic-acid (18:0) and a rise in oleic-aicd (18:1) percentage concentrations, a rise in palmitic-acid $(16: 0)$ percentage concentration, and a fall in linoleic-aicd (18:2) percentage concentration. The percentage concentration of arachidonic acid (20:4) rose. The resolution between a number of long chain fatty acids was not sufficiently precise to register comparatively small changes. The results in both the treated and the untreated groups are compared to the fatty acid patterns of normal young adults and of an unselected group of geriatric patients in table VI.

Clinical progression on clofibrate is compared to progress during a pretreatment period of similar duration in fig. 4. Using the criteria laid down in a previous paper (Dormandy et al.,

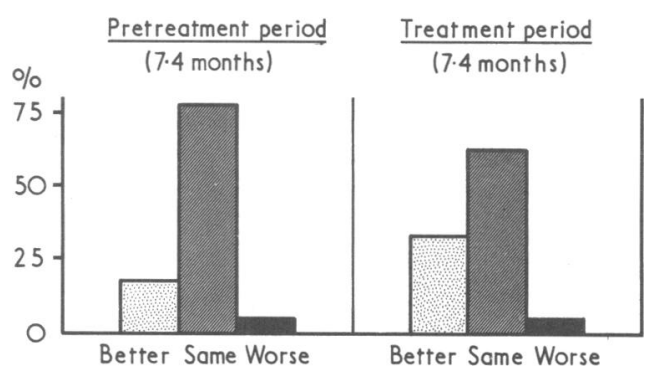

FIG. 4-Clinical progress of 62 patients before treatment and over a similar period on clofibrate. 
TABLE vI-Percentage Composition of Red-cell Fatty Acids in Healthy Adults, in Geriatric Patients, in Untreated Patients with Intermittent Claudication, and in patients with Intermittent Claudication treated with Clofibrate

\begin{tabular}{|c|c|c|c|c|}
\hline \multirow{2}{*}{ Fatty Acid } & \multirow{2}{*}{$\begin{array}{l}\text { Healthy Adults } \\
\text { aged } 20-40 \text { Years } \\
(\mathrm{n}=10)\end{array}$} & \multirow{2}{*}{$\begin{array}{l}\text { Unselected Elderly Subjects } \\
\text { aged 70-90 Years } \\
(\mathrm{n}=25)\end{array}$} & \multicolumn{2}{|c|}{ Patients with Intermittent Claudication } \\
\hline & & & Untreated $(n=27)$ & On Clofibrate $(n=60)$ \\
\hline $\begin{array}{l}16: 0 \text { (Palmitic) } \\
18: 0 \text { (Stearic) } \\
18: 1 \text { (Oleic) } \\
18: 2 \text { (Linoleic) } \\
20: 4 \text { (Arachidonic) } \\
22: 0 \\
22: 4 \\
22: 5+24: 0 \\
22: 6+24: 1 \\
26: 0\end{array}$ & 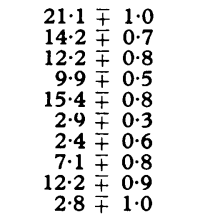 & $\begin{array}{rl}24.7 & \mp 1.2 \\
15.7 & 1.4 \\
14.5 & 0.9 \\
7.2 & 1.6 \\
13.7 & 1.5 \\
2.6 \mp & 0.4 \\
1.8 & 0.4 \\
5.8 & 0.8 \\
11.3 & 1.1 \\
2.8 & 1.0\end{array}$ & 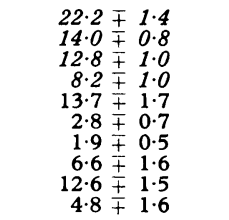 & $\begin{aligned} 23.5 \mp & 1.0 \\
13.3 \mp & 0.7 \\
13.9 \mp & 0.9 \\
7.5 \mp & 0.6 \\
14.6 \mp & 0.8 \\
2.5 \mp & 0.4 \\
2.0 \mp & 0.2 \\
6.2 \mp & 1.6 \\
11.2+ & 1.7 \\
4.7 \mp & 1.3\end{aligned}$ \\
\hline
\end{tabular}

Significant differences $(P<0.001)$ between treated and untreated patients with claudication are italicized.

1973 a) 10 patients improved and three became worse during the pretreatment period, most remaining unchanged. On treatment the three patients continued to deteriorate but the number of those improving increased from 10 to 21 . Since the trial was not double-blind and the period of observation was comparatively short no useful attempt can be made to analyse the rest of the clinical data.

\section{Discussion}

Though the trial reported here was too brief for a firm evaluation of clinical changes it showed that clofibrate altered a number of rheological and chemical characteristics which can reasonably be expected to influence clinical progress. In particular, the drug induced a steep and sustained fall in blood viscosity measured over a wide range of shear rates. If, as seems probable, these measurements reflect blood viscosity in the circulation such a fall would lead to a significant increase in the blood supply to the limbs (Dormandy, 1971). Both experimental and statistical evidence links the effect of viscosity with a fall in plasma fibrinogen. This fibrinogen-lowering action of clofibrate, though well-recognized, has received less attention than the changes brought about by the drug in plasma lipids, yet from the point of view of ischaemic symptoms and signs it is almost certainly of greater importance.

Blood behaves as a non-Newtonian fluid-that is, the relation between shear rate and viscosity is non-linear-for different reasons at different shear rates. At high shear rates the nonNewtonian behaviour depends largely on the "deformability" of individual cells, a function of their physical consistence and chemical character. At low shear rates it becomes more and more a reflection of the flow-retarding effect of cell aggregation, largely a function of plasma factors. One cannot, of course, assume that decreasing shear rates in a viscometer accurately reflect declining speeds at which blood flows in the body (even assuming that this speed is constant and uniform at any one point), but it seems reasonable to assume that whereas measurements at high shear rates may be relevant to blood-flow in the larger arteries measurements at low shear rates reflect conditions in the micro-circulation. For this reason additional measurements at low shear rates may prove an important advance, and it is not unexpected that they show the effect of clofibrate most clearly.

Among other chemical variables which might influence blood viscosity a further period of observation confirmed the correlation between viscosity and the susceptibility of the red cells to autoxidation (two-hour MDA). Fatty acid analysis shows that this increased susceptibility is not simply a function of more autoxidizable material per gramme of heamoglobin.

Though clofibrate is known to affect plasma fatty acids the well-marked changes in the red cell fatty acid pattern were unexpected. Some of these changes, particularly the fall in the percentage concentration of linoleic acid (18:2), might at first sight seem disquieting as they tend to be associated with ageing and with degenerative disease. On general grounds, however, the rise in the percentage concentration of arachidonic acid $(20: 4)$ must be regarded as a "favourable" effect, suggesting that clofibrate may not so much depress essential fatty acid concentration as promote the conversion of linoleic to arachidonic acid. This in turn raises the question whether any beneficial effect the drug may have on arterial disease (as distinct from affording relief from some of its clinical manifestations) might be conditional on an increased supply of linoleic acid.

There can be little doubt that viscosity measured under proper conditions over a wide spectrum of shear rates reflects an important and at times critical determinant of peripheral blood flow. Intermittent claudication is, however, a complex syndrome, and only a more extensive controlled double-blind trial can finally settle how far viscosity and chemical changes brought about by clofibrate will influence the clinical course of the disease.

We thank Professor David Slome, Mr. Lionel Gracey, and Mr. John Davis for their help. T. L. D. wishes to acknowledge the financial support of the N. E. Thames Regicnal Health Authority.

\section{References}

Cotton, R. C., Wade, E. G., and Spiller, G. W. (1963). Fournal of Atherosclerosis Research, 3, 648.

Dormandy, J. A. (1970). Annals of the Royal College of Surgeons, 47, 211.

Dormandy, J. A. (1971). British Medical fournal, 4, 716.

Dormandy, J. A., et al. (1973 a). British Medical fournal, 4, 576.

Dormandy, J. A., et al. (1973 b). British Medical fournal, 4, 581 .

Gutteridge, J. M. C., Stocks, J., and Dormandy, T. L. (1973). Clinica Chimica Acta, 48, 317.

Merrill, E. W. (1969). Physiological Reviews, 49, 863.

Phillips, G. B., Dodge, J. T., and Rockmore, C. S. (1968). Fournal of Lipid Research, 9, 285 .

Physicians of the Newcastle upon Tyne Region. (1971). British Medical Fournal, 4, 767.

Research Committee of the Scottish Society of Physicians (1971). British Medical fournal, 4, 775 .

Stocks, J., et al. (1972). British fournal of Haematology, 23, 713.

Weaver, J. P. A., Evans, A., and Walder, D. (1969). Clinical Science, 36, 1 Wells, R. E., et al. (1964). American fournal Physiology, 207, 1035. 